\title{
The Effectiveness of Content Based Instruction In Teaching Speaking Skill For EFL Learners
}

MA Darul Aitam Jerowaru, Indonesia

\author{
Rabi'atul Adawiyah
}

Correspondence: Rabi'atul Adawiyah, Indonesia. e-mail: hajjahabiiy@gmail.com

Received: August 1, 2018

doi: 10.29408/veles.v2i2.846.g587
Accepted: September 1, 2018

Online Published: September 15, 2018

URL: http://dx.doi.org/10.29408/veles.v2i2.846.g587

\begin{abstract}
This study aimed at examining the effectiveness of content based instruction method in teaching speaking skills of EFL learners. This research was a pre-experimental research with pre-test and post-test design. It was conducted at the eleventh grade of MA Darul Aitam Jerowaru in the school year 2017-2018. The sample consisted of 27 students selected by cluster random sampling. The data was collected using a speaking test. In addition to diescriptive statistics the collected data were submited to a paired sample t-test. The mean score of post-test (53.62) was higher than that of pre-test (33.48). The result of the paired sample t-test indicated that there was a significant difference in the mean scores between pretest and post-test, $t_{(\mathrm{df}=26)}=77.53$ at $p<.01$. Based on the finding, it can be concluded that content based instruction was an effective method to teach speaking.
\end{abstract}

Keywords: content based instruction (CBI) method, speaking skills

\section{Introduction}

Speaking is the active way to express people's thoughts and give oral information to other people. It is similar to the definition of speaking stated by Tarigan (1985, p.17). He states that speaking is one of the language skills in oral form to express the speaker's ideas to everybody. He also defined that speaking is the informal interchange of thought and information by spoken words. In other chance, Tarigan (1981, p. 3) also states that "speaking is one of language skill that develop in children's life begin from listening, in the same time where speaking is learnt". This statement proves that speaking is a process that closely related to listening process.

English is one of the considered languages that is used in communication. In Indonesia, English is the first foreign language which is very important to be learned by students, starting from elementary schools up to universities. Nowdays, almost all of the instructions around the world, including in Indonesia are written in English. Starting from how to operate the electrocic machines, how to cook the foods and many more. English is important to be mastered by students because English plays an important role in developing and spreading the technology and science. Therefore, Indonesian students should master English well.

There are four skills in teaching and learning English, those are listening, speaking, reading, and writing. Those skills are relted to each other and cannot be independent. 
Therefore, learners need to master all of the four skills. This is supported by Uma and Ponnambala (as cited in Titis Dewi Cakrawati 2012) state that "mastering language skills will determine the students' communicative competence in the target language."

Speaking is one of four important skills in English. Therefore English Teacher Education Students should have a good speaking skill. Richard (as cited in Juhana 2008) says "most students often evaluate their success in language learning as well as the effectiveness of their English course on the basis of how much they fell they have improved in their speaking proficiency." Speaking is a productive skill which used the combinations of pronunciation, vocabulary, grammar and even accent. Therefore, when the students speak English well and very often they may think that they have improved another ability which involves within speaking. The fact that speaking is transient and improvised. Therefore, can be viewed as facile, superficial, or glib.

Speaking is difficult skill to be learned because it is related to the way of expressing one idea or arguments. Based on my interview in MA Darul Aitam Jerowaru, most of students especially the students of senior high school find some difficulties when they are going to deliver their minds orally in English. The difficulties in speaking may be caused by the lack of vocabulary, nothing to say, and nervous. So, in this case the teachers should create a competitive method in teaching and learning process of the foreign language, in arranging words the teachers need to be creative in finding or designing the teaching, learning media and method. One of the good method to improve the students' speaking skill is by using content based instruction (CBI) in order to build an interesting teaching learning process.

Brinton, Snow, and Wesche (as cited in Jasone Cenoz 2015) define " content based instruction (CBI) as the concurrent study of language and subject matter with the form and sequence of language presentation dictated by content material." Even though there are older examples of content based instruction (CBI) its origins are usually associated with Canadian immersion programmes which is the best known example of content based instruction (CBI). Content Based Instruction (CBI) is to abandon the pastlearning language method, and learning the language in a subject or a certain subject content of teaching so that students can improve their speaking ability in the classroom. Content based instruction (CBI) refers to the teachers according to a subject of organization of teaching materials, to around the subject of teaching materials. So that the students to enhance their English Speaking Skill. Based on this fact, the present researcher chooses Content Based Instruction (CBI) as the method in this research because Content Based Instruction (CBI) is one of simple method. This is easy and effective to apply in teaching and learninng process in Senior High School.

Based on the phenomenon above, the present researcher intends to use Content Based Instruction (CBI) to teach speaking skill for the eleventh grade students of MA Darul Aitam Jerowaru in the school year 2017-2018.

\section{Method}

\subsection{Participants}

This study used a pre-experimental research with pre test and post test design since this study concerns with investigeting the effectiveness of Content Based Instruction (CBI) method in teaching speaking skills for EFL learners. 
The population of this study was all of the eleventh grader students of MA Darul Aitam Jerowaru in the school year 2017-2018 which consists of three classes with the total numbers of population were 81 students. Then the resercher took one class as the sample which had 27 students.

\subsection{Data Collection}

\subsubsection{Instrument of Collecting Data}

To obtain the data, the researcher used a speaking test (story telling) was given to measure the students' speaking ability. Brown (2004) mentions "the speaking test aims at finding out assessment of the speaker's use of fluency, grammar, vocabulary, pronounciation, and comprehension."

Table 1. Scoring Rubric of Speaking Skill

\begin{tabular}{|c|c|c|}
\hline Elements & Score & Criteria \\
\hline \multirow[t]{5}{*}{ Fluency } & 5 & Speak very fluently, native-like fluency. \\
\hline & 4 & Speak less fluently due to few problems of vocabulary. \\
\hline & 3 & $\begin{array}{l}\text { Occasionally have problems in speaking due to selection of } \\
\text { words, so that the are several pauses during speaking. }\end{array}$ \\
\hline & 2 & Regular pauses and hesitancy \\
\hline & 1 & Very slow speaking due to serious language problems. \\
\hline \multirow[t]{5}{*}{ Grammar } & 5 & $\begin{array}{l}\text { Very few mistakes without deducing the meaning of } \\
\text { information. }\end{array}$ \\
\hline & 4 & $\begin{array}{l}\text { Accosionally making mistakes, e.g. order or words, but the } \\
\text { meaning can be understood. }\end{array}$ \\
\hline & 3 & $\begin{array}{l}\text { Making several mistakes, thus repetition is necessary to } \\
\text { strengthen meaning. }\end{array}$ \\
\hline & 2 & Making many mistakes, so that meaning is unclear. \\
\hline & 1 & Making regular mistakes so that it is difficult to understand. \\
\hline \multirow[t]{5}{*}{ Vocabulary } & 5 & Accurate selection of words, native speaker-like. \\
\hline & 4 & $\begin{array}{l}\text { Very few mistakes in word selection, but it does not deduce the } \\
\text { meaning. }\end{array}$ \\
\hline & 3 & $\begin{array}{l}\text { Accosionally uses inaccurate words, so that clarification of } \\
\text { meaning is necessary. }\end{array}$ \\
\hline & 2 & $\begin{array}{l}\text { Regular wrong uses of words which make meaning difficult to } \\
\text { understand. }\end{array}$ \\
\hline & 1 & $\begin{array}{l}\text { Serious problems in using accurate words, so that it is unable to } \\
\text { undertand. }\end{array}$ \\
\hline \multirow[t]{5}{*}{ Pronounciation } & 5 & Accurate pronounciation with native-like accent. \\
\hline & 4 & Accurate pronounciation witn mother tongue accent. \\
\hline & 3 & Good pronounciation with one or two mistakes. \\
\hline & 2 & $\begin{array}{l}\text { Having problems in pronounciation, thus it is difficult to } \\
\text { comprehend. }\end{array}$ \\
\hline & 1 & Having problems in pronounciation, thus it is unable to \\
\hline
\end{tabular}




\begin{tabular}{lll}
\hline comprehension & \multicolumn{2}{c}{ comprehend. } \\
\cline { 2 - 3 } 4 & $\begin{array}{l}\text { Very good understanding of the material so that the story could } \\
\text { be expresses nicely. }\end{array}$ \\
\hline 3 & $\begin{array}{l}\text { Good understanding of the material, but occasionally make } \\
\text { repetitions in expressing the story. }\end{array}$ \\
& $\begin{array}{l}\text { Having comprehension problems, but not serious and directly } \\
\text { understand after having some repetitions so that the story could } \\
\text { be expressed. }\end{array}$ \\
\hline 2 & $\begin{array}{l}\text { Having difficulties to comprehend the material so that unable } \\
\text { to express the story. }\end{array}$ \\
\hline 1 & $\begin{array}{l}\text { Unable to comprehend the material so that unable to express } \\
\text { the story. }\end{array}$ \\
\hline
\end{tabular}

Brown (2004)

Table 2. Scoring Interpretation

\begin{tabular}{cc}
\hline Score & Category \\
\hline $80-100$ & Very High \\
$60-79$ & High \\
$40-59$ & Modest \\
$20-39$ & Low \\
$00-39$ & Very Low \\
\hline
\end{tabular}

\subsubsection{Techniques for Collecting Data}

In this study, the researcher evaluated the students' speaking ability more detail and objective, their speaking performance in pre test and post test were recorded. Based on the topic of oral test or speaking. The samples were asked to tell the folklore in front of the class based on their understanding maximal 5 minutes.

\subsection{Data Analysis}

To obtain the data, the present researcher used the descriptive statistics to analyze the data. The data that were analyzed here were the mean score pre test and post test and the standard deviation. To find out the data, the present researcher used SPSS 22 for Windows.

Table 03. Descriptive Statistics

\begin{tabular}{lllll}
\hline & Mean & N & Std. Deviation & Std. Error Mean \\
\hline Pretest & 33,4815 & 27 & 10,11613 & 1,94685 \\
Posttest & 53,6296 & 27 & 9,75132 & 1,87664 \\
\hline
\end{tabular}


Furthermore, the statistics for testing hypothesis, those were normal distribution test and homogeneity test in which both statistics were analyzed by using SPSS Statistics 22 for windows. The result of normality and homogeneity can be seen in Table $\mathbf{4}$ and Table 5 as follows:

Table 4. Test of Normality

\begin{tabular}{lllllll}
\hline & \multicolumn{4}{l}{ Kolmogorov-Smirnov $^{\mathrm{a}}$} & \multicolumn{4}{l}{ Shapiro-Wilk } \\
\cline { 2 - 7 } Pretest & Statistic & df & Sig. & Statistic & df & Sig. \\
Posttest &, 122 & 27 &, $200^{*}$ &, 935 & 27 &, 094 \\
\hline
\end{tabular}

Table 5. Test of Homogeneity

Pre-Post

$\begin{array}{llcc}\text { Levene Statistic } & \text { df1 } & \text { df2 } & \text { Sig. } \\ , 088 & 1 & 52 & , 768\end{array}$

Meanwhile, for the hypothesis testing by using paired sample t-test. The present researcher found that there was a significant difference in the mean scores between the pretest and post-test, $t_{(\mathrm{df}=26)}=77.53$ at $p<.01$, it means that there was the significantly effective of content based instruction method on students' speaking skills at the eleventh graders of $M A$ Darul Aitam Jerowaru in the school year 2017-2018.

\section{Findings}

The result of the data calculated showed that the mean score of experimental group in pre-test was 33.48 and in post-test was 53.62. Meanwhile, the standard deviation of the pretest was 10.11 and post-test was 9.75. Based on the data gained of students' speaking skill, it was indicated that the existence of a tendency that mean score after having the treatment was higher than before having treatment, in which the mean score of post-test was higher than the mean score of pre-test.

Meanwhile, for the hypothesis testing by using paired sample t-test. The present researcher found that there was a significant difference in the mean scores between the pretest and post-test, $\mathrm{t}(\mathrm{df}=26)=77.53$ at $\mathrm{p}<.01$, it means that there was the significantly effective of content based instruction method on students' speaking skills at the eleventh graders of MA Darul Aitam Jerowaru in the school year 2017-2018.

Table 06. Paired Samples Test

\begin{tabular}{lllll}
\hline & & $\mathrm{t}$ & $\mathrm{df}$ & Sig.(2-tailed) \\
Pair 1 & Posttest - Pretest & 77,532 & 26 &, 000 \\
\hline
\end{tabular}




\section{Discussion}

The goal of this study were to find out the effectiveness of content based instruction (CBI) method on students' speaking skill for the eleventh graders at MA Darul Aitam Jerowaru in the scholl year 2017-2018 and how is the effectiveness of content based instruction (CBI) method on students' speaking skill for the eleventh graders at MA Darul Aitam Jerowaru in the school year 2017-2018.

In the case of the ENL speakers, the result of the study has revealed that there are five factors which may have substantial relationship to intelligibility; word pronunciation accuracy, word stress, lexical accuracy, adjustments in connected speech, and sentence stress. Among these factors, word stress has turned out to be the most significant factor for intelligibility. As far as the ESL speakers are concerned, there are also five factors which may predict intelligibility; word pronunciation accuracy, word stress, sentence stress, intonation, and rhythm.

In this case, during the content based instruction method activity in the classroom, the students explore their ability especially in speaking to create some new words given based on initial of word, find out some words based on the letters in one word provided, construct a word based on the firs letter of every words in a sentence provided, find out an object that has double characteristics, find out the unusual usage of daily things, and the ability to find the effect of the event based on the task that teachers give, and making the students interested with the new folklore that they get. As the researcher found during the process, the students were still lacking in the ability to speak in the used of English. Therefore, the researcher tried to applyed the CBI method in the learning process to determine the effectiveness of the CBI method as well as the extent to which students can be active in learning process through the CBI method also is used with a variety of different meanings that refers to the substance or subject matter that the students learn or communicate through language rather than the language convey it. It is believed that is good becouse it provides natural context for using the target language in the classroom in which the focus of learning is in content of what is being taught, so students can acquire the content area with a subject matter applied in learning process. That is make the content based istruction an effective method in joining teaching and learning process in MA Darul Aitam Jerowaru students.

In addition, the application of content based instruction (CBI) is useful and interesting method because it gives every student an opportuity to speak and it reflect to speak. However, during the treatments, it was observed that few students tended to do less effort to keep their presentation and conversation on and tended to do less practice in speaking, they also get low in vocabulary, comprehension, and grammar. So that's why their and conversation on and tended to do less practice in speaking. However, with the motivation and encouragement of the teachers, even the students were able to explore their ability to speak better than before even they like to be presented interesting folklore. So, they are not left behind of some students who have easily mastered the material during the teaching and learning process. So, that why the content based instruction is effective to the students with low learning.

The results of this research supported the previous research which was conducted by Aisyah Sunarwan (2014) showing that content based instruction is recommended to apply in 
teaching English especially in speaking skill. Also, the finding of the present research also consistent with Stoller (2008) idea that content based instruction is an umbrella term for approcehes that combine language and content learning aims even if there are differences in the emphasis placed on language and content. Morever, the language teacher can obtain the benefit from this method in educating more active students in other to be better communicators, and also always give the students a motivations and encouragement for making students happy and interested to study more better than before, that is one of steps to be a professional teachers. So whenever in the new materials teachers can use the content based instruction in teaching learning.

\section{Conclusions}

Based on the results, the present researcher concludes briefly that content based instruction (CBI) method was significantly effective especially for the eleventh graders at MA Darul Aitam Jerowaru. The value of post-test was higher than the value of pre-test. It means that the standard deviation and mean score were significant. We can conclude that the students after treatment were better than before. Then, after processing the data, the researcher concluded that there was an effectiveness of content based instruction (CBI) method on students' speaking skill for eleventh graders at MA Darul Aitam Jerowaru in the school year 2017-2018. It was known because there was significant differences between mean score of pre-test and mean score of post-test.

Based on the conclusion above, the researcher suggests the teachers, for the students and for the other researchers can be listed as follows: for the teachers, teachers should have some method to enrich their English teaching method, teachers suggeted to be more creative in teaching speaking, because by treating them with some good method, the students will be challenged to be more enthusiasms in studying English especially in speaking skills. For the students, students should be more excited in practicing English especially speaking skill without having any fear to be corrected by the others because of doing grammatical errors, wrong dictions and bad pronounciation, students also should practice more every time because only by the way the students can speak English fluently. Meanwhile, the content based instruction (CBI) method can be one of the alternative method to be used in drilling their English. For the other researchers, a replication of this research design using content based instruction (CBI) as teaching method in teaching speaking can be done with some revision. A similar research to different population characteristic is also possible.

\section{References}

Brown, H. (2001). Teaching by principle an interactive approach to language pedagogy. San Francisco: Longman.

Brown, H. (2004). Language assessment: principles and classroom practice. New York: Pearson Education.

Cakrawati, T.D. (2012). The effect of using communicative cartoon movies on the teaching of writing skill. Yogyakarta: Yogyakarta University Press. Published. 
Cenoz, J. (2015). Content based instruction and language integrated learning: the same different? Journal of Language, Culture and Curriculum, 28 (1), 8-24. Retrived from July 02, 2016, http://dx.doi.org.10.1080/2014.1000922.

Hill, R. (2012). What sample size is enough in internet survey research? Journal of Interpersonal Computing and Technology, 6 (3-4). Retrived from May 2012, http://www.dx.org.researchgate.net.

Juhana. (2012). Psychological factors that hinder students from speaking in English class. Journal of Education and Practice, 12, 2222-1735. Retrived from January 2012, htttp://www.iiste.org.

Kosar, G., \& Bedir, H. (2014). Strategies based instruction: a means of improving adult EFL learners' speaking skill. Journal of Language Academy, 12, 2342-0251. Retrived from December 2014, http://www.doi.org.

Khairuddin. (2005). The effectiveness of discussion method toward speaking skill for the second grade students of SMPN 1 Praya Lombok Tengah in the school year 2004/2005. Unpublish undergraduate thesis of STKIP Hamzanwadi Selong.

Moedjito. (2016). Basic statistic for research in language education. Selong: Yuma Pustaka.

Nuraini, K. (2016). The barriers of teaching speaking english for EFL learners. Journal of English, Language, Literature and Teaching, 14, 2528-0066. Retrived from May 2016, http://www.journalecth.ac.id.

Nurmasya', Anita. (2014). Improving the speaking ability. Yogyakarta: Yogyakarta University Press. Published.

Sunarwan, Aisyah. (2014). The effectiveness of content based instruction to teach speaking viewed from students' creativity, 3 (1), 2089-3345. Retrived from April 2014, http://www.ccsnet.org/journal/indexphp/elt/artic171252.

Sugiyono. (2012). Metode penelitian pendidikan. Bandung: Alfabeta.

Wathani. (2006). English speaking skill for the second year students of SMA NW Pancor in the school year 2005/2006. Unpublished undergraduate thesis of STKIP Hamzanwadi Selong. 